\title{
Applying typological insights in a minority-language context: Motion event lexicalisations in Ladin, Italian, German and English texts compiled by Ladins
}

\begin{abstract}
This paper investigates the lexical choices made by speakers of Ladin in describing the opening scene of Mayer's (1969) Frog, where are you? in Ladin and in the other languages they learnt later in life (Italian, German and English). The focus of the investigation is on motion lexicalisation, which varies across languages in terms of preferred encoding patterns (Talmy 1985, 2000; Wälchli 2001). Relative frequencies are calculated for the variants occurring in the different languages, before turning to a qualitative discourse-analytic approach, which forms the core of the analysis. The results are discussed with reference to the fields of typology and cross-linguistic research. The analysed texts bring to the fore the necessity of distinguishing between national and regional idioms and the potential value of drawing cross-linguistic issues to the explicit attention of learners. Possible implications are considered with reference to the novel framework of Applied Language Typology (Filipović 2018).
\end{abstract}

KEYWORDS: motion events, cross-linguistic comparison, typology, Ladin, learner language.

\section{INTRODUCTION}

There seems to be a growing interest in the application of typological insights in several domains that demand an understanding of linguistic diversity, such as the description of languages with different statuses and their learning or teaching. Typological issues have received attention in the domain of dialectology (Berthele 2004, 2006). Moreover, typological frameworks have been argued to provide crosslinguistic analyses of learner scripts with theoretical grounding, thus contributing to giving a better account and interpretation of learner data (Giacolone Ramat 2003; Kashyap 2019). The study of possible practical consequences of typological contrasts has been taken up with a view to enhancing communication in different professional contexts and has come under the definition of Applied Language Typology (Filipović 2008, 2017a, 2017b, 2018).

The present analysis of learner data was inspired by the linguistic typology of motion events. The study understood motion event encoding constructions as verb-phrases that denoted a figure's self-movement resulting in a change of 
location, e.g. a frog's exit from an imprisoning jar, and movement occurring at approximately the same place, e.g. a series of hops around a room. Motion verbs were taken to include the deictic verbs come and go and transitive verbs expressing self-motion, e.g. leave a place. The analysis concerned the expression of motion in narrative texts compiled by adolescents in their native tongue and in three languages they learnt later in life: Dolomitic Ladin (L1), Italian (L2), German (L3), and English (L4) ${ }^{1}$. While motion verbs have sparked intense attention over the past years, they have remained largely unexplored in the Dolomitic Ladin variety spoken in Northern Italy. Ladin is also virtually absent from studies involving different learner language combinations.

This paper aimed to investigate the motion lexicalisation patterns that occurred in a number of Ladin (L1), Italian (L2), German (L3), and English (L4) narrative extracts from a contrastive linguistics perspective. It intended to ascertain whether the identified lexicalisation patterns conformed to typological expectations as described in Section 2 and whether word choices could be explained in terms of crosslinguistic influence. The following specific questions were addressed in the study:

1. What are the preferred lexicalisation patterns for motion in the learner texts?

2. Which motion verb heads are favoured in the four participant languages?

3. Which learner language displays the highest ratio of motion verb types and tokens?

4. Which are the most common locative adverbs and prepositions?

5. How prominent is the expression of manner?

Section 2 presents the typological foundation that underpinned the study, Section 3 describes the research procedure, and Section 4 reports the key findings, which are discussed in Section 5. The paper concludes by suggesting that typological and crosslinguistic findings can feed into teaching and improve professional practice.

\section{THEORETICAL CONSIDERATIONS}

The presented study drew in particular on insights from Talmy $(1985,2000)$, Wälchli (2001), and Berthele $(2004,2006)$. Talmy $(1985,2000)$ found that languages differ in the way they generally lexicalise the motion elements of path and manner. Verb-framed languages (e.g. standard Italian) characteristically express the route followed by the moving figure in the verb root, whereas the

\footnotetext{
${ }^{1}$ Italian and German are indicated as L2 and L3 for ease of reference, although they could both be argued to be second languages, learnt and used inside and outside of school.
} 
manner of motion is described optionally outside of the main verb, e.g. Italian Entrò correndo / di corsa 'He entered running'. Satellite-framed languages (e.g. German and English) typically lexicalise the manner of movement in the main verb, while path is expressed in a separate adverbial or prepositional complex, e.g. English He ran into the house (Talmy 2000). Languages often exhibit a combination of verb-framed and satellite-framed properties. They can be situated on a cline between the different typological poles and display various degrees of manner and path salience (Slobin 2004, 2006; Ibarretxe-Antuñano 2009). Due to an abundance of locative adverbs, the Romance minority language Ladin is at the high path salience end, along with Germanic languages, but it has a low diversity of manner verbs in comparison to satellite-framed languages, and a high frequency of use of the verb ji ' $g o$ '.

Berthele $(2004,2006)$ argued that Rhaeto-Romance is not to be catalogued as verb-framed like other Romance languages, since it displays many satellite-framed features, such as the extensive use of directional adverbs. In his analyses of Swiss German and Rhaeto-Romance varieties, Berthele $(2004,2006)$ argued that dialects are conceptually oral and exhibit: lower type-token ratios in the lexicon, more complex structures, and a greater frequency of semantically light or general verbs.

Wälchli (2001: 301) identified three main loci for the encoding of path: "(V) verbal encoding (i.e. by the verb stem), (AN) adnominal encoding (i.e. by prepositions, postpositions or case marking), and (AV) adverbal encoding (i.e. by verb affixes or verb particles)". The latter includes Talmy's (1985: 102) satellites, namely "certain immediate constituents of a verb root other than inflections, auxiliaries, or nominal arguments". Stolova (2015) suggested including elements from Latin INDE 'from there, thence' in the concept of satellite. The present study therefore classified Ladin and Italian composite verbal forms with a reflexive pronoun and an unaccented locative adverb from INDE as V + ADV (verb + adverbial), e.g. Ladin s'un sciampé 'reflexive $+<\mathrm{INDE}+$ escape' or s'un ji 'reflexive $+<\mathrm{INDE}+$ $g o^{\prime}$. Details on the study subjects, stimulus material, and analysis procedure are provided in Section 3.

Table 1 summarises the types described above and provides examples of typical patterns.

Table 1. Language types and examples

\begin{tabular}{|l|l|l|l|}
\hline Language & \multicolumn{1}{|c|}{ Frame } & \multicolumn{1}{c|}{ Manner } & \multicolumn{1}{c|}{ Examples } \\
\hline Ladin & Satellite-framed & Low-manner & gnì ca y ite dlun saltan 'come hither-and-in running' \\
\hline Italian & Verb-framed & Low-manner & Entrò di corsa. 'She entered running.' \\
\hline German & Satellite-framed & High-manner & Lara stürmte herein. 'Lara rushed in.' \\
\hline English & Satellite-framed & High-manner & Sarah rushed in. \\
\hline
\end{tabular}




\section{METHOD}

\subsection{Participants and languages}

Four groups of participants produced written texts in four different languages, as Table 2 illustrates. 42 subjects wrote in Ladin (L1), 22 in Italian (L2), 21 in German (L3), and 73 in English (L4). The participants all spoke Ladin as their first language and had learnt Italian, German, and English at school. They were between 12 and 14 years of age (mean age approx. 13.5) and attended a lower secondary school. At the moment of data collection, the pupils had enjoyed a different number of lessons in the different languages. While Italian and German receive the same amount of attention in Ladin schools, English is taken up later and is dedicated less time. The third column of Table 2 presents the number of hours of language tuition that primary and lower-secondary schools provide in total. Since most study participants were halfway through their last year of lowersecondary school, the hours of exposure to the languages at school were slightly fewer than the ones indicated in Table 2. The participants were at an advanced level of Italian and German and at a post-elementary level of English in terms of writing. Despite the different status of the languages considered and the different level of proficiency the learners had achieved in them, they were treated together in order to gain an overall picture of the language repertoire of Ladin speakers.

Table 2. Language instruction at the Ladin compulsory schools in South Tyrol

(Provincial guidelines 2009)

\begin{tabular}{|l|c|c|}
\hline Languages & Number of texts produced & $\begin{array}{c}\text { Hours of language instruction } \\
\text { at primary and lower-secondary school }\end{array}$ \\
\hline Ladin L1 & 42 & 511 \\
\hline Italian L2 & 22 & 1292 (+ medium of instruction) \\
\hline German L3 & 21 & 1292 (+ medium of instruction) \\
\hline English L4 & 73 & 307 \\
\hline
\end{tabular}

The data were collected in the northern Italian province of South-Tyrol. The Ladin variety examined in the present paper belongs to Dolomitic Ladin and is spoken in the upper part of Val Badia.

\subsection{Stimulus}

The four groups of Ladin pupils completed a story prompted by an abridged version of Mayer's (1969) wordless picture book Frog, where are you? The well- 
-known series of pictures features a boy looking for his run-away pet frog. They boy's searching adventure begins when he wakes up in the morning and realises that the glass jar where the pet frog was supposed to be is empty. Instructions were given to the participants in Ladin, but they were kept to a minimum, with no indication on how the writing would be scored or analysed. The pupils were asked to complete the story in a written form, individually, and with no dictionary. The task was unrehearsed and did not form a part of formal assessment.

\subsection{Analysis procedure}

The present study examined the initial part of the narrative texts, with the aim of determining how the participants described this particular scene in one of their four languages. More precisely, it was observed how the participants completed the initial sentences that were provided to them in the language they had to use (see Figure 1).

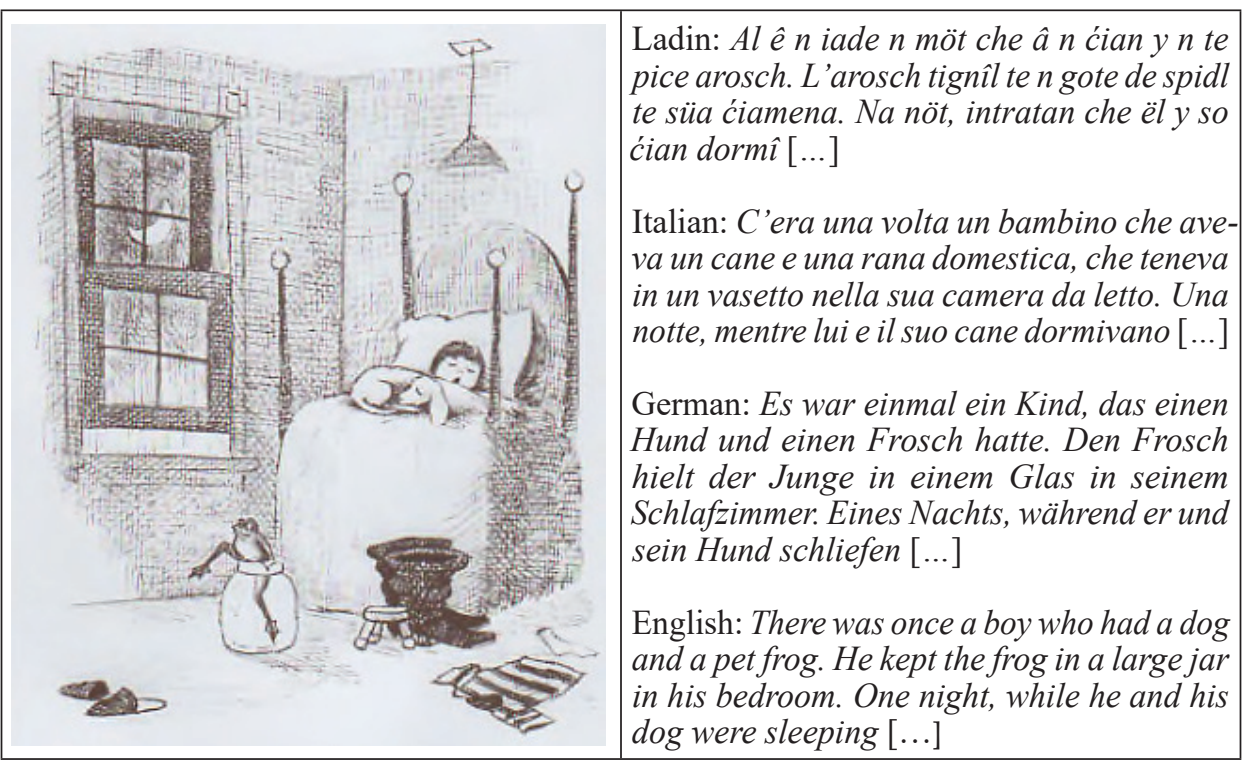

Figure 1. Beginning of the story

Picture source: Mayer 1969

The cut-off point was set at the first full stop as placed by the learners. Table 3 shows the total number of words that was analysed for each language and the number of words produced on average by each learner. 
Table 3. Number of words analysed

\begin{tabular}{|l|c|c|}
\hline \multicolumn{1}{|c|}{ Languages } & Number of words analysed & Average number of words per learner \\
\hline Ladin L1 & 508 & 12,09 \\
\hline Italian L2 & 306 & 13,91 \\
\hline German L3 & 270 & 12,86 \\
\hline English L4 & 599 & 8,20 \\
\hline
\end{tabular}

The Ladin, Italian, German, and English texts were searched for descriptions of motion. Combinations of motion verbs with other linguistic elements were observed to detect the loci for the encoding of path on the basis of suggestions by Wälchli (2001), Berthele (2004, 2006), and Spreafico (2009). The data were scrutinised to find the preferred motion event constructions in the four languages. It was observed whether the learner groups showed a preference for bare motion verbs $(\mathrm{V})$, for verbs accompanied by an adnominal ( $+\mathrm{ADN})$, or for verbs with an adverbial construction $(\mathrm{V}+\mathrm{ADV})$. The most common motion verb heads were subsequently identified, and type-token ratios were computed. The locative adverbs and prepositions that occurred in the texts were finally examined, before briefly considering the expression of manner. The investigation yielded the results presented in Section 4 and discussed in Section 5 .

\section{RESULTS}

\subsection{Motion event constructions}

It was emphasised by Wälchli (2001) that motion event encoding constructions are frequently formed by a combination of the verbal root $(\mathrm{V})$ with adverbial (ADV) and adnominal phrases (ADN), constructions that Ladin, Italian, German, and English all support. Table 4 shows the range of the different loci that was identified in our data. It can be noticed that the preferred lexicalisation pattern for motion was constituted by a verbal plus adnominal expression in all the languages considered. This is in line with findings by Bernini, Spreafico, and Valentini (2006), who found a preference for the expression of path in the adnominal locus in Italian L2 narratives produced by speakers of German and Dutch. Bare verbs came next in terms of preference in Italian, whereas Ladin, German, and English preferred adverbial constructions. 
Table 4. Motion event constructions in Ladin, Italian, German, and English $(100 \%=$ the total number of motion verb constructions)

\begin{tabular}{|c|c|c|c|c|}
\hline Constructions & Ladin L1 & Italian L2 & German L3 & English L4 \\
\hline $\mathrm{V}+\mathrm{ADN}$ & $69 \%$ & $70 \%$ & $64 \%$ & $74 \%$ \\
\hline $\mathrm{V}$ & $3 \%$ & $27 \%$ & $12 \%$ & $4 \%$ \\
\hline $\mathrm{V}+\mathrm{ADV}$ & $26 \%$ & $3 \%$ & $18 \%$ & $19 \%$ \\
\hline $\mathrm{V}+\mathrm{N}$ & $2 \%$ & $/$ & $3 \%$ & $4 \%$ \\
\hline $\mathrm{V}+$ Inf. V & $/$ & $/$ & $3 \%$ & $/$ \\
\hline
\end{tabular}

The motion verbs occurring in the texts were most often accompanied by a noun phrase that indicated the source or origin of the motion trajectory, namely the jar where the story frog had been kept as a pet, as illustrated in examples (1)-(5), which exemplify the construction V + ADN. ${ }^{2}$

(1) Na nöt, intratan che ël y so ćian dormî, s' nen êl l'arosch sciampéfora de gote. (L1) ${ }^{3}$ 'One night, while he and his dog were sleeping, REFL-PRON was-3M the frog escaped out of jar.'

(2) ...la rana è saltata fuori dal vasetto. (L2) $)^{5}$

'...the frog is jumped out of the jar.'

(3) ...la rana usci dal vasetto. (L2)

'...the frog exited from the jar.'

(4) ...hüpfte der Frosch aus dem Glas. (L3)

'...jumped the frog out of the jar...'

(5) ...jumped out of the jar. (L4)

The use of bare verbs $(\mathrm{V})$ in the Italian, German, and English narratives is illustrated in (6)-(8).

(6) ...la rana domestica scapò. (L2)

'...the pet frog escaped.'

${ }^{2}$ An in-depth analysis of the categorial status of out in constructions of the type of out of the glass lies beyond the scope of the present investigation.

${ }^{3}$ In order to avoid unnecessary repetition, the italicised temporal clause, which was provided in the stimulus material, will be replaced by three dots in the following examples.

${ }^{4}$ The examples are translated freely into semi-idiomatic English.

${ }^{5}$ The data consist of unedited learner texts and therefore contain spelling errors and inaccuracies. 
(7) ...flüchtete der Frosch. (L3)

'...fled the frog.'

(8) ...her frog jumped and go. (L4)

Ladin sciampé 'escape' occurred as a bare or non-reflexive form only in paratactic clauses that described a complex event, as in example (9).

(9) ...salta le arosch fora dal gote y sciampa. (L1) '...jumps the frog out of the jar and escapes.'

Examples (10)-(13) show the use of motion verbs accompanied by directional adverbs $(\mathrm{V}+\mathrm{ADV})$ in each language, with a stronger preference for this construction in Ladin, German, and English, as illustrated in Table 4 above.

(10) ...se n'é sciampé demez. (L1)

'...REFL + < INDE is escaped away.'

(11) ...la rana saltò fuori. (L2)

'...the frog jumped out.'

(12) ...hüpfte der Frosch weg. (L3)

'...jumped the frog away.'

(13) ...the frog ran away. (L4)

\subsection{Motion verb heads}

Similar lexical preferences were exhibited in the Ladin L1 and Italian L2 texts, on the one hand, and in the German L3 and English L4 texts on the other. The Ladin and Italian scripts favoured the equivalent of the English motion verb escape, while the German and English texts showed a preference for jump. Tables 5 and 6 show that the most frequent motion verb heads in the Ladin and Italian texts were sciampé (Ladin) and scappare (Italian) < Vulgar Latin EXCAPPĀRE, EX 'out of' CAPPA 'cape', literally 'get out of one's cape, leave a pursuer with just one's cape' (Bonomi 2004-2008; Harper 2001-2019). The verb scappare 'escape' was also used by almost all research subjects in the Italian L2 texts collected by Bernini, Spreafico and Valentini (2006).

Table 5. Lexical types and tokens in Ladin L1

\begin{tabular}{|l|c|c|}
\hline \multicolumn{1}{|c|}{ Ladin L1 lexical types } & Instances & Percentages \\
\hline sciampé 'escape' & 33 & 57 \\
jì 'go' & 11 & 19 \\
salté 'jump' & 7 & 12 \\
gní 'come' & 6 & 10 \\
lascé ‘leave' & 1 & 2 \\
\hline 5 types & 58 tokens & $\mathbf{1 0 0}$ \\
\hline
\end{tabular}


Table 6. Lexical types and tokens in Italian L2

\begin{tabular}{|l|c|c|}
\hline \multicolumn{1}{|c|}{ Italian L2 lexical types } & Instances & Percentages \\
\hline scappare 'escape' & 12 & 36 \\
uscire 'exit' & 8 & 24 \\
saltare 'jump' & 4 & 12 \\
cadere 'fall' & 3 & 9 \\
fuggire 'escape' & 2 & 6 \\
andare 'go' & 2 & 6 \\
arrampicarsi 'climb' & 1 & 3 \\
saltellare 'hop' & 1 & 3 \\
\hline 8 types & 33 tokens & $\mathbf{1 0 0}$ \\
\hline
\end{tabular}

Table 7 shows that the preferred verb of motion in the German learner texts was hüpfen 'jump', related to English hop < Old English hoppian < Proto-Germanic *hupnojan (Harper 2001-2019).

Table 7. Lexical types and tokens in German L3

\begin{tabular}{|l|c|c|}
\hline \multicolumn{1}{|c|}{ German L3 lexical types } & Instances & Percentages \\
\hline hüpfen 'jump' & 10 & 30 \\
gehen 'go' & 4 & 12 \\
schlüpfen 'slip' & 4 & 12 \\
kommen 'come' & 3 & 9 \\
springen 'jump' & 2 & 6 \\
rennen 'run' & 2 & 6 \\
schleichen 'creep' & 2 & 6 \\
fliehen 'flee' & 1 & 3 \\
verschwinden 'disappear' & 1 & 3 \\
flüchten 'escape' & 1 & 3 \\
laufen 'run' & 1 & 3 \\
steigen 'climb' & 1 & 3 \\
verlassen 'leave' & 1 & 3 \\
\hline 13 types & $\mathbf{3 3}$ tokens & $\mathbf{1 0 0}$ \\
\hline
\end{tabular}

Table 8 shows that the most frequent verb of motion in the English texts was jump, which was followed closely on the list of frequencies by the deictic verbs go and come.

Table 8. Lexical types and tokens in English L4

\begin{tabular}{|l|c|c|}
\hline \multicolumn{1}{|c|}{ English L4 lexical types } & Instances & Percentages \\
\hline jump & 25 & 31 \\
go & 23 & 28 \\
come & 21 & 26 \\
run & 6 & 7 \\
leave & 3 & 4 \\
climb & 1 & 1 \\
get & 1 & 1 \\
fall & 1 & 1 \\
\hline 8 types & $\mathbf{8 1}$ tokens & $\mathbf{1 0 0}$ \\
\hline
\end{tabular}


The verbs come and go accounted for more than half of the instances of the motion verbs in the English learner texts, as reported in Table 9. Come and go also represented a good portion of the motion verbs in Ladin, followed by German, whereas they hardly occurred in the Italian learner texts at all.

Table 9. Go and come in Ladin, Italian, German, and English $(100 \%=$ the total number of motion verb tokens)

\begin{tabular}{|l|c|c|c|c|}
\hline \multicolumn{1}{|c|}{ Verbs } & Ladin L1 & Italian L2 & German L3 & English L4 \\
\hline Go & $19 \%$ & $6 \%$ & $12 \%$ & $28 \%$ \\
\hline come & $10 \%$ & $/$ & $9 \%$ & $26 \%$ \\
\hline Total & $\mathbf{2 9} \%$ & $\mathbf{6} \%$ & $\mathbf{2 1} \%$ & $\mathbf{5 4} \%$ \\
\hline
\end{tabular}

\subsection{Verb types and tokens}

Verbs that expressed motion from one place to another accounted for a high percentage of the total number of verb-phrase tokens in all the languages considered, as the figures reported in Table 10 illustrate. The highest percentage was found in the English learner scripts, where almost all the verbs that were used expressed motion. Verbs of motion accounted for the lowest percentage in Italian, where verbs of non-motion provided further details and were quite common, e.g. to explain that the frog could not sleep and that the boy did not notice anything.

Table 10. Percentage of motion verb tokens in Ladin, Italian, German, and English $(100 \%=$ the total number of verb-phrase tokens $)$

\begin{tabular}{|c|c|c|c|}
\hline Ladin L1 & Italian L2 & German L3 & English L4 \\
\hline $75 \%$ & $61 \%$ & $66 \%$ & $90 \%$ \\
\hline
\end{tabular}

The figures reported in Table 11 show that the German learner texts displayed the highest ratio of motion verb types and tokens, whereas the Ladin and English texts had the lowest ratio. As could also be seen in Tables (5), (6), (7), and (8) above, the highest number of different verbs of motion was identified in the German data, whereas the list of different motion verbs was rather short in English, and even shorter in Ladin.

Table 11. Type-token ratio of the motion verbs in Ladin, Italian, German, and English

\begin{tabular}{|c|c|c|c|}
\hline Ladin L1 & Italian L2 & German L3 & English L4 \\
\hline $9 \%$ & $24 \%$ & $39 \%$ & $10 \%$ \\
\hline
\end{tabular}




\subsection{The most common locative adverbs and prepositions}

The stimulus material that was employed invited the use of the complex preposition out of to relate the frog's exit from the jar. Out of occurred in a high proportion of texts in all the languages examined, especially in English and German, where it followed $67 \%$ and $64 \%$ of the motion verbs. The predominant adverbs in English and German were away and weg, which accompanied 19\% of the English and 15\% of the German motion verbs. None of the participants used the preposition from in English and none double-marked the source with German heraus or hinaus, e.g. aus dem Glas heraus 'out of the jar out' (with a deictic orientation), unlike a number of Bamberg's (1994) adult subjects, who added this deictic spatial perspective.

The only adverbs that were identified by Bernini, Spreafico, and Valentini (2006) in the Italian learner texts they examined were fuori 'out' and via 'away'. As few as $9 \%$ of the motion verbs were accompanied by fuori 'out' in our Italian data, whereas via was completely absent. The Ladin adverb demez 'away' occurred three times. The motion verbs in the Italian learner texts were mostly followed by the articled preposition dal 'from the', which preceded nouns that indicated different motion sources and routes, such as the confining jar, the pet keeper, and the escaping route, as illustrated in (14).

(14) ... scappò dal vasetto / dal perfido bambino mangia animali / dalla finestra. (L2)

'...escaped from the jar / from the wicked animal-eating child / from the window.'

Ladin fora 'out' accompanied 59\% of the motion verbs and was mostly followed by a bare or articled preposition, which took on different forms, e.g. de, $d l$ and dal, as illustrated in (15).

(15) ...sciampé... fora de gote / fora $d l$ gote / fora dal gote ala liberté. (L1)

'...escaped... out of glass / out of the glass / out from the glass into the freedom.'

Whether the clauses in (15) are equally well-formed is open to discussion. Ladin exhibits a wide range of count singular nominals that can be preceded by fora de 'out of' without article. One of the numerous examples is bëre fora de gote 'drink out of glass', where no particular glass is singled out by the bare nominal, whereas the nominal preceded by the articled preposition in bëre fora dl gote'drink out of the glass' indicates a specific glass in question. In the context of the cur-

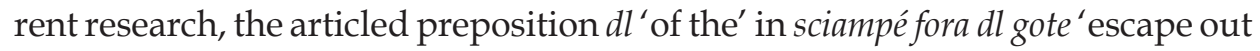


of the glass' seemed to be preferable to the bare preposition $d e$, as the research subjects confirmed. The acceptability of the articled preposition dal in sciampéfora dal gote 'escape out of the glass' is highly debatable. In fact, it would be judged as odd or even as wrong by many speakers of the language, who might point out that sciampé fora dal + nominal would indicate a target of motion rather than its source. Surprisingly, a good number of research participants were of a different opinion, since fora dal gote was produced as often as fora $\mathrm{dl}$ gote in our data ${ }^{6}$.

Fora 'out' occurred in different sentence positions, as illustrated in (16). In the first clause, fora precedes the articled preposition and noun, whereas in the second clause it follows the noun. Da finestra fora indicates the route from one side of the window to the other.

(16) ... le arosch sciampe fora dale gote y snun e sciampe da finestra fora. (L1) '....is the frog escaped out of the jar and REFL-PRON is escaped from the window out.'

\subsection{Manner}

The expression of manner appeared to be most prominent in the German texts, which preferred the manner verb hüpfen 'jump' and exhibited a whole series of other verbs encoding manner. Although the English scripts also used the manner verb jump most often, the expression of path seemed to be generally preferred by the learners, who frequently used the deictic verbs of motion go and come with no indication of motion whatsoever. The favourite Ladin and Italian verbs sciampé and scappare 'escape' might be viewed as mixed, since they denote both path (i.e. implying motion away from a ground) and manner (i.e. motion that is quick and stealthy) (Spreafico 2009). The Italian and Ladin verb heads saltare and salté 'jump' came next in terms of favourite manner verbs. The latter are "verbs that encode particular force dynamics - high energy motor patterns that are more like punctual acts than activities" (Slobin 2006: 67) and therefore also occur with boundary crossing in verb-framed languages such as standard Italian.

Manner was hardly ever described outside of the main verbs in any language. An example is given in (17), where the way of moving is described by the German adverb leise 'quietly'.

(18) ...hüpfte sein Frosch leise aus dem Glas. (L3)

'...jumped his frog silently out of the jar.'

${ }^{6}$ The use of Ladin fora 'out' to indicate geographical directions will be pursued in a future project. 


\section{DISCUSSION}

Revisiting the specific research questions in Section 1 , the analysis revealed that: (1) the participants favoured the lexicalisation pattern composed by a verbal and adnominal expression in Ladin (L1), Italian (L2), German (L3), and English (L4); (2) the preferred motion verb heads were the equivalent of English escape in the Ladin and Italian texts, while the German and English scripts favoured jump; (3) the highest type-token ratio was obtained in the German learner texts; (4) the complex preposition out of featured prominently in all the languages, while adverbs were hardly ever present in Italian; (5) no language devoted particular attention to manner outside of the main verb. The results prompted a series of reflections as discussed below.

The preferred lexicalisation patterns for motion identified in the learner texts were in line with the typological characteristics of the languages considered. Typologically, the Italian learner texts conformed to the verb-framed pattern characteristic of standard Italian, which normally favours bare verbs with no further elaboration of path by means of adverbs. The German and English learner texts exhibited a satellite-framed tendency by preferring adverbials to bare verbs, thus adhering to the typical lexicalisation pattern identified for German and English. In the context of the present study, the strong tendency of Ladin towards the satellite-framed adverbial pattern was largely determined by its extensive use of composite forms with SE and INDE. The data showed that Ladin is a high-path salient language that describes escaping scenes mainly with reflexive satellite-framed compounds ${ }^{7}$.

A number of lexical choices brought about reflections on crosslinguistic issues or transfer. While sciampé and scappare 'escape' were the most common verbs in the Ladin and Italian texts, the verb escape did not occur even once in the English texts, despite its Latin base and similarity to the Ladin and Italian forms, which were thus not transferred into English. The main lexical choices that were made by the learners (e.g. escape in Ladin and Italian, and jump in German and English) suggest a lexical transfer operating from Ladin L1 into Italian L2 and from German L3 into English L4. Similarly, Jessner $(2006,2008)$ found that German was the most influential language in the production of English texts by South-Tyrolean German-Italian bilinguals. In line with Rothman's (2011, 2015)

${ }^{7}$ The reflexive pronominal forms s'un ji 'REFL + < INDE + go' and s'un sciampé 'REFL $+<$ INDE + escape' also seemed to assign a pleonastic-intensifying value to the adverb demez 'away', which occurred three times in the Ladin data. If demez 'away' accompanies the reflexive forms of sciampé 'escape' and $j i$ ' 'go', it seems to reiterate and thus emphasise information that is already expressed by the verbs themselves, i.e. the escape or motion away from a source. 
typological primacy model, psychotypology might play a role in the production of English texts by multilingual speakers of Ladin, who might perceive German to be their closest language to English. The fact that Ladin schools tend to use German as a support language in their English classes might strengthen the learners' feeling that English is closer to German and indirectly encourage them to resort to German rather than to Italian in case of lexical gaps.

Another verb that was hardly present in the English learner texts was climb, which might have been a natural choice in the description of an amphibian's exit from a jar. The fact that only one pupil used climb in this context shows that learners were unfamiliar with the multiple contexts of use of this English verb, which does not correspond to its Ladin and Italian counterparts in terms of usage. Unlike English climb, Ladin se arampiché / se arpizé and Italian arrampicarsi 'climb' are normally not employed to describe someone's exit from an enclosed space, e.g. climbing out of a jar, bath, car, or taxi. Like English climb, German klettern and steigen are used to indicate movement in various directions and in various contexts, e.g. klettert / steigt aus dem Wagen 'climbs out of the car', klettert / steigt aus der Wanne 'climbs out of the bathtub' ${ }^{8}$ The English and German verbs climb and klettern are acquired by learners at a beginner level, but their wide context of use becomes familiar to them at a much later stage, as confirmed by Irsara (2017a).

Although English is a high-manner salient language with a large number of different verbs to express ways of moving, the low type-token ratio in the learner texts was not particularly surprising, given the relatively low amount of English tuition the pupils had enjoyed. The fact that the motion verbs in the English texts accounted for a higher percentage of the total number of verb-phrases than in the other languages was also to be expected, considering that lower-proficiency learners tend to concentrate and to limit themselves to a description of "what is most salient as new information in the pictures, which is typically the movement itself" (Aksu-Koç 1994: 532). It might have come as a surprise that the type-token ratio was even lower in the learners' first language, which might be expected to exhibit higher lexical richness and diversity than languages mastered at a lower level. An explanation for the low type-token ratio of motion verbs in Ladin is provided by the regional and predominantly oral character of the language, which tends to make extensive use of a small repertoire of motion verbs in different contexts. This supports Berthele's (2004) argument that the dimension of orality vs. literacy needs to be considered in studies with a typological and contrastive perspective. Finally, the highest ratio in the German texts appears to challenge the general assumption that pupils in Val Badia are more proficient

\footnotetext{
${ }^{8}$ German also has the form erklimmen 'to scale / crest something' < Old High German klimban, Middle High German klimben, with assimilation klimmen.
} 
in Italian than in German. On the other hand, the higher lexical richness in the German scripts might be due to the high manner salience of German, which "provides rich possibilities for detailed description of motion in a given direction in a given manner" (Bamberg 1994: 220). Finally, a number of occurring verbs might be argued to be contextually rather anomalous, e.g. rennen and laufen 'run' to describe a frog's way of moving.

The majority of the motion verbs identified in all the languages were followed by a prepositional phrase indicating the jar that had kept the pet frog imprisoned, e.g. Italian dal, German aus, English out of + source. A comparison of the prepositional phrases that occurred in the texts seems to reveal reverse or backward transfer from Italian (L2) to Ladin (L1). The participants' use of the articled preposition (fora) dal, instead of the more appropriate (fora) $d l$, must have been determined by the existence of the identical form dal in Italian. The wide use of the debatable fora dal + source in the Ladin texts might be an example of a generational difference in the use of the language and interpreted as change in progress. The pattern motion verb + fora dal + source seems to be poorly tolerated by older speakers but broadly accepted by the younger generations, whose contact with Italian and other languages has generally increased.

The texts examined revealed barely any instances of manner descriptions in phrasal or clausal expressions outside of the main verbs. Providing additional information on the manner of movement seems to be a heavy strategy in terms of processing load (Slobin 2004). It is therefore reasonable to assume that the participants did not put much effort into the writing task and instead limited themselves to describing the most salient points. On the other hand, both native and learner patterns might omit peripheral manner markings in order to avoid overemphasising the manner information and making the text awkward to read (Verkerk 2014). Still, the addition of optional manner adjuncts might sometimes improve the quality of written narrative texts by making them lexically richer and more elaborate. It will therefore be argued in the next section that learners might derive benefits from a teaching emphasis on the use of motion verbs and a number of related issues raised above.

\section{CONCLUSIONS, LIMITATIONS, AND IMPLICATIONS}

The present paper illustrated how insights from linguistic typology can be implemented in crosslinguistic analyses of native and learner texts. This smallscale study does clearly not allow categorical statements or final conclusions on the expression of motion in general. The investigation was restricted to one specific static scene, and differences in language status and proficiency levels 
needed to be kept in mind throughout the analysis as possible explanations for the results. Despite these limitations, the analysis gave us a general picture of tendencies in a population of speakers who performed a specific task in a specific context. Four groups of Ladin speakers from Northern Italy described an escaping scene in Italian, German, English, and in their native tongue, Ladin. The text analysis captured a number of phenomena pertinent to linguistic typology and transfer. The Ladin speakers who compiled their narratives in Italian had a stronger tendency to employ bare verbs with no further elaboration of path by means of adverbs than their Ladin counterparts who wrote in the other languages. The Italian learner texts inclined towards the verb-framed typology for motion events, while the German and English extracts showed satellite-framed tendencies. The Ladin narratives revealed a high propensity to describe escaping events with verb-phrases incorporating a reflexive pronoun and a clitic from Latin INDE, which was argued to form satellite-framed compounds.

Crosslinguistic influence was identified in the absence of certain verbs in English and in a number of lexical and morphological preferences exhibited in the texts. The very limited use of the verb climb in the English learner texts was explained by the more restricted contexts of use of this verb in Ladin and in Italian. In contrast, the absence of the Latin-based verb escape in English could not be justified with reference to transfer. The similar forms sciampé and scappare in Ladin and in Italian were not transferred into English by the learners. Reverse or backward transfer from Italian into Ladin was identified in the use of the debatable fora dal 'out of the' + source in a number of Ladin texts, which appeared to be morphologically heterogeneous but lexically simple and repetitive. The frequent occurrence of the basic verbs come and go across the English texts was justified by the learners' lower level of proficiency in this language, while the repeated use of jí'go' and gni 'come' is a characteristic feature of Ladin, which is a regional language with a mainly oral tradition, despite the existence of written literature and spelling norms.

Bringing typological and crosslinguistic differences and similarities in the description of motion events to the explicit attention of learners might be beneficial for their learning process. This was also proposed by Irsara (2017b) in her illustration and application of a multilingual teaching model, and by Filipović (2017a, 2017b, 2018) in her discussion of the Applied Language Typology approach. Typologically informed language classes might lead speakers of low-manner first languages to consciously extend their repertoire of manner-of-motion verbs when learning a high-manner salient target language. Crosslinguistic teaching interventions might also facilitate positive transfer, which does not seem to be as automatic as sometimes assumed. Finally, language classes incorporating typological and crosslinguistic findings might disclose characteristic features 
of their first languages to unaware learners, who might therefore have their metalinguistic knowledge increased. The latter might be particularly valuable in minority-language situations, where multiple linguistic systems often interact on a daily basis and regional varieties are highly prone to changing.

\section{REFERENCES}

Aksu-Koç, A. A. (1994). Development of linguistic forms: Turkish. In: R. A. Berman / D. I. Slobin (eds.). Relating events in narrative: A crosslinguistic developmental study (pp. 329-386). Hillsdale, NJ: Lawrence Erlbaum.

Bamberg, M. (1994). Development of linguistic forms: German. In: R. A. Berman / D. I. Slobin (eds.). Relating events in narrative: A crosslinguistic developmental study (pp. 189-238). Hillsdale, NJ: Lawrence Erlbaum.

Bernini, G. / Spreafico, L. / Valentini, A. (2006). Acquiring motion verbs in a second language: The case of Italian L2. Linguistica e Filologia, 23, 7-26.

Berthele, R. (2004). The typology of motion and posture verbs: A variationist account. In: B. Kortmann (ed.). Dialectology meets typology: Dialect grammar from a cross-linguistic perspective (pp. 93-126). Berlin / New York: Mouton de Gruyter.

Berthele, R. (2006). Ort und Weg: Die sprachliche Raumreferenz in Varietäten des Deutschen, Rätoromanischen und Französischen. Berlin / New York: Walter de Gruyter.

Bonomi, F. (2004-2008). Dizionario etimologico online. https:/ / www.etimo.it/?term=scappare\&find= Cerca [access: 9.05.2020].

Filipović, L. (2008). Typology in action: Applying insights from typological contrasts. International Journal of Applied Linguistics, 18 (1), 42-61.

Filipović, L. (2017a). Applied language typology: Applying typological insights in professional practice. Languages in Contrast, 17 (2), 255-278.

Filipović, L. (2017b). Applying language typology: Practical applications of research on typological contrasts between languages. In: I. Ibarretxe-Antuñano (ed.). Motion and space across languages: Theory and applications (pp. 399-418). Amsterdam / Philadelphia: John Benjamins.

Filipović, L. (2018). Language contrasts in translation: Cognitive and practical consequences. In: K. Rasulić / I. Trbojević (eds.). Belgrade English language and literature studies (vol. 10): Special issue in honour of Ranko Bugarski on the occasion of his $85^{\text {th }}$ birthday (pp. 39-65). Belgrade: Čigoja štampa.

Giacalone Ramat, A. (ed.). (2003). Typology and second language acquisition. Berlin / New York: De Gruyter.

Harper, D. (2001-2019). Online etymology dictionary. http:/ / www.etymonline.com/ [access: 25.07.2019]. Ibarretxe-Antuñano, I. (2009). Path salience in motion events. In: J. Guo / E. Lieven / N. Budwig / S. Ervin-Tripp / K. Nakamura / Ş. Özçalışkan (eds.). Crosslinguistic approaches to the psychology of language: Research in the tradition of Dan Isaac Slobin (pp. 403-414). New York: Psychology Press.

Irsara, M. (2017a). Pictures meet words: Learners of English describing motion situations. Proceedings of the international and interdisciplinary conference IMMAGINI? (Brixen, Italy, 27-28 November 2017), 1 (9), 928.

Irsara, M. (2017b). Promoting cross-linguistic awareness: English motion events in a multilingual teaching model. Lingue e Linguaggi, 23, 121-132.

Jessner, U. (2006). Linguistic awareness in multilinguals: English as a third language. Edinburgh: Edinburgh University Press. 
Jessner, U. (2008). Teaching third languages: Findings, trends and challenges. Language Teaching, 41 (1), 15-56.

Kashyap, A. K. (2019). Language Typology. In: G. Thompson / W. Bowcher / L. Fontaine / D. Schönthal (eds.). The Cambridge handbook of systemic functional linguistics (pp. 767-792). Cambridge: Cambridge University Press.

Mayer, M. (1969). Frog, where are you? New York: Dial Books for Young Readers.

Provincial guidelines for primary and lower-secondary schools in the Ladin localities (2009). http:/ / www. provinz.bz.it/formaziun-lingac/scora-ladina/it/pubblicazioni.asp [access: 9.05.2020].

Rothman, J. (2011). L3 syntactic transfer selectivity and typological determinacy: The typological primacy model. Second Language Research, 27 (1), 107-127.

Rothman, J. (2015). Linguistic and cognitive motivations for the Typological Primacy Model (TPM) of third language (L3) transfer: Timing of acquisition and proficiency considered. Bilingualism: Language and Cognition, 18 (2), 179-190.

Slobin, D. I. (2004). The many ways to search for a frog: Linguistic typology and the expression of motion events. In: S. Strömqvist / L. Verhoeven (eds.). Relating events in narrative: Typological and contextual perspectives (vol. 2) (pp. 219-257). Mahwah, NJ: Lawrence Erlbaum Associates.

Slobin, D. I. (2006). What makes manner of motion salient? Explorations in linguistic typology, discourse, and cognition. In: M. Hickmann / S. Robert (eds.). Space in languages: Linguistic systems and cognitive categories (pp. 59-81). Amsterdam / Philadelphia: John Benjamins.

Spreafico, L. (2009). Problemi di tipologia lessicale: I verbi di moto nello Standard Average European. Rome: Bulzoni Editore.

Stolova, N. I. (2015). Cognitive linguistics and lexical change: Motion verbs from Latin to Romance. Amsterdam / Philadelphia: John Benjamins.

Talmy, L. (1985). Lexicalization patterns: Semantic structure in lexical forms. In: T. Shopen (ed.). Language typology and syntactic description (pp. 57-149). Cambridge: Cambridge University Press.

Talmy, L. (2000). Toward a cognitive semantics (vol. 2). Cambridge, MA: MIT Press.

Verkerk, A. (2014). Where Alice fell into: Motion events from a parallel corpus. In: B. Szmrecsanyi / B. Wälchli (eds.). Aggregating dialectology, typology, and register (pp. 324-354). Tubingen: De Gruyter.

Wälchli, B. (2001). A typology of displacement (with special reference to Latvian). Sprachtypologie und Universalienforschung, 54 (3), 298-323.

Received: 28.08.2019; revised: 21.03.2020

\author{
MARTINA IRSARA \\ Libera Università di Bolzano \\ Martina.Irsara@unibz.it \\ ORCID: 0000-0002-5710-1262
}

